Ashil: Jurnal Pendidikan Anak Usia Dini

Vol. 1 No. 1, April 2021. e-ISSN: 2776-4117

https://doi.org/10.33367/piaud.v1i1.1506

Journal Ashil

Submitted:

Revised:

13-01-2021

15-01-2021

Accepted:

Published:

03-02-2021

24-04-2021

\title{
Terapi Realitas untuk Meningkatkan Penerimaan Ibu yang Memiliki Anak Berkebutuhan Khusus di Kabupaten Nganjuk
}

\author{
Wahyu Utami ${ }^{1}$, Sun Fatayati ${ }^{2}$ \\ Institut Agama Islam Tribakti Kediri \\ ${ }^{1}$ ayoe utami@ymail.com, ${ }^{2}$ sunfatati@iai-tribakti.ac.id
}

\begin{abstract}
Abstrak
Diperkirakan $20 \%$ anak berkebutuhan khusus dilahirkan oleh ibu yang berusia diatas 35 tahun. Beberapa kasus masyarakat cenderung menjauhi individu dengan kebutuhan khusus tidak jarang dari mereka juga menghina bahkan dikucilkan. Lebih parahnya penolakan ini tidak hanya dilakukan oleh masyarakat umum, juga oleh keluarga dan orangtua. Sampel Subjek dalam penelitian ini adalah ibu rumah tangga dengan rentang usia 35-41 tahun. Teknik pengambilan sampel menggunakan purposive sampling dengan kriteria orangtua yang memiliki anak anak berkebutuhan khusus dengan skala rendah dalam penerimaan pada anak anak berkebutuhan khusus. Metode penelitian menggunakan observasi, wawancara dan skala pengukuran penerimaan orangtua pada anak. Intervensi yang diberikan pada subjek ialah terapi realitas sebanyak 9 sesi. Hasil intervensi menunjukkan bahwa paired t-test diperoleh nilai t hitung sebesar 11,731 dengan nilai signifikansi sebesar $0,000(\mathrm{p}<0,05)$ sehingga data yang terdapat pengaruh pemberian perlakuan terhadap data test. Hal tersebut menunjukkan bahwa orangtua dengan tingkat penerimaan anak dengan anak berkebutuhan khusus dapat meningkat melalui pemberian terapi realitas. Artinya adalah penelitian ini menunjukkan adanya penurunan tingkat penolakan ibu terhadap anak.
\end{abstract}

Kata kunci: Terapi realitas, Penerimaan orangtua, Anak berkebutuhan khusus

\begin{abstract}
It is estimated that $20 \%$ of children with special needs are from mothers who are over 35 years old. In some cases, people tend to stay away from individuals with special needs, not infrequently, they are also humiliated and even isolated. Worse, this rejection is not only done by the general public, but also by families and families. Sample subjects in this study were housewives with an age range of 35-41 years. The sampling technique used purposive sampling with the criteria of parents who have children with special needs on a low scale in the acceptance of children with special needs. The research method uses observation, interviews and children's measurement scales. The intervention given to reality therapy subjects was 9 sessions. The results of the intervention showed that the t-test pair obtained the t-test value of 11,731 with a significance value of $0.000(p<0.05)$ so that the
\end{abstract}

Ashil: Jurnal Pendidikan Anak Usia Dini is licensed under a Creative Commons Attribution-ShareAlike 4.0 International License. 
existing data had the effect of treatment on the test data. This shows that parents have an increased level of acceptance of children with special needs through the provision of reality therapy. This means that this research shows a decrease in the response rate of mothers to children.

Keywords: Reality therapy, Parental acceptance, Children with special needs

\section{PENDAHULUAN}

Jumlah anak berkebutuhan khusus yang semakin meningkat dengan tidak diimbangi dengan peningkatan pemahaman dan pemakluman masyarakat terhadap kondisi mereka, hal tersebut guna untuk mencegah penolakan di banyak tempat. Di beberapa tempat, anak berkebutuhan khusus cenderung dikucilkan, dianggap dengan sebelah mata, secara terang-terangan diejek dan dihina. Penolakan tidak hanya dari lingkungan sekitar, tetapi juga dilakukan oleh keluarga inti. Anak terlahir dengan kondisi yang sehat, tanpa cacat tentu menjadi harapan setiap orangtua. Hasil penelitian menunjukkan bahwa adanya peningkatan tingkat pengucilan sosial, artinya Seperti orang tua dari anak-anak dengan kecacatan intelektual mengalami lebih banyak batasan pada kehidupan sosial mereka, upaya yang dilakukan keluarga adalah dengan merahasiakan kondisi atau menarik diri dari orang lain (Yang, Nhan, Shin \& Ngo, 2012)

Saat seseorang yang dinanti tidak sesuai dengan kondisi yang diinginkan, berbagai reaksi emosi negatif dimunculkan para orantua dan mimpi orangtua seketika sirna. Hasil penelitian yang dilakukan oleh (Faradina, 2016) menunjukkan bahwa kehadiran anak berkebutuhan khusus menimbulkan perasaan khawatir, cemas, tertekan dan stress pada orangtua dan hasil penelitian menunjukkan bahwa ibu merasakan tanggungjawab dan reaksi emosi yang lebih besar dibanding anggota keluarga lainnya. Hasil penelitian yang dilakukan oleh Levianti (2013) menunjukkan bahwa ibu memiliki penerimaan yang baik dikarenakan beralasan ingin menjadi ibu yang baik dan membantu anaknya untuk dapat menjadi seseorang yang tidak putus asa dan mandiri, sehingga pengasuhan pada anak berjalan dengan optimal.

Reaksi emosi negatif tersebut secara tidak langsung akan berdampak pada pengasuhan orangtua terhadap anak, keterlibatan dalam membesarkan anak tidak 
terlepas dari peran orangtua, baik ibu dan ayah mempunyai cara tersendiri dalam mempengaruhi anak, hal tersebut erat kaitannya dalam pembentukan kepribadian dan kesuksesan dalam tahap-tahap perkembangan anak khususnya pada anak berkebutuhan khusus. Hasil penelitian oleh Save \& Dagun (1992) tokoh ayah akan memberi bantuan kepada anak melalui penerapan berbagai kisah pengalaman yang berguna bagi perkembangan kognitif anak. Sementara itu, sisi feminim yang ada pada diri ibu membantu tahap perkembangan emosional anak berkebutuhan khusus.

Bagi kebanyakan orang tua, kelahiran anak mereka adalah saat yang menggembirakan. Namun, diperkirakan 4\% dari orang tua menerima kabar kurang baik mengenai kondisi anak mereka, bahkan setiap 3,5 menit orang tua diberitahukan bahwa anak mereka mengalami kondisi kronis secara medis, cacat kesehatan, cacat tubuh, gangguan sensorik, atau keterbelakangan mental (March of Dimes, 2000). Bagi orang tua, kondisi kelahiran anak mereka yang dianggap tidak normal bisa menjadi permasalahan seperti munculnya stres dan keputusasaan. Orangtua membutuhkan kesabaran dalam merawat dan membesarkan anak berkebutuhan khusus sehingga keduanya dapat merasakan kebahagiaan. Hal tersebut menunjukkan bahwa pada saat apa yang diinginkan tidak sesuai dengan harapan, sulit bagi orangtua untuk menerima segala kondisi anak.

Sejumlah penelitian telah mendokumentasikan tuntutan emosional dan kondisi fisik yang unik menjadi faktor penyebab hilangnya kebahagiaan pada orangtua seperti stres dan ketegangan orang tua membesarkan anak dengan kondisi medis kronis atau kecacatan (Florian \& Findler, 2001) dan depresi kronis (Flaherty \& Galyden, 2000), memiliki perasaan yang bertentangan, depresi, rendah diri serta kesehatan mental yang rendah (Ross, 2005). Serangkaian reaksi emosi yang muncul saat anak di diagnosis berkebutuhan khusus merupakan respon alamiah yang pada orangtua sebelum sampai pada tahap menerima.

Ginanjar (2008) menyebutkan reaksi emosi yang dialami orangtua antara lain: (1) Terkejut dan menolak diagnosa, reaksi ini merupakan reaksi yang kerapkali dimunculkan orangtua saat anaknya pertamakali didiagnosis berkebutuhan khusus. Beberapa orangtua memperlihatkan sikap menolak 
kenyataan, para orangtua berusahan mendapatkan diagnosa yang lebih tepat dengan datang ke dokter dan ahli lain. (2) Merasa tidak berdaya, respon ini sering muncul pada saat orangtua mengetahui beberapa informasi terkait kondisi anak dari berbagai sumber yang berakhir pada rasa bingung, tidak berdaya karena orangtua akan menghadapi situasi dimana orangtua harus melakukan banyak hal untuk menangani kondisi anak (3) Emosi negatif (sedih, cemas akan masa depan anak, malu karena kondisi anak yang berbeda, serta merasa bersalah dan berdosa).

Penerimaan pada diri adalah individu yang memiliki penghargaan pada diri sendiri, bersikap ramah kepada lawan dan pada diri sendiri (Supratiknya, 1995). Pendapat lain mengatakan segala sesuatu yang berkaitan padaaspek diri atau kehidupan individu sebagai bagian dari diri orang tersebut (Dilman, 2005). Pendapat lain oleh (Dariyo, 2007) merupakan bentuk kemampuan seseorang mampu dalam menerima penerimaan pada diri sendiri. Seligman (dikutip Mangunsong, 2011), terdapat beberapa tahapan sesorang individu berada badaa tahap menerima, 1) menolak, 2) menawar, 3) marah, 4) depresi, 5) penerimaan. Hurlock (2005) ada beberapa faktor yang dapat mempengaruhi penerimaan diri pada seseorang, yaitu keinginan yang realistis, keberhasilan, pengenalan pada diri, pengetahuan sosial dan konsep diri yang stabil. Terjadinya ketimpangan antara ideal self orangtua dan real self, ketika orangtua harus menerima keterbatsan anak tersebut maka akan menyebabkan konsep self yang dimiliki orangtua menjadi incongruensi atau tidak saling sesuai. Keadaan yang incongruensi ini beresiko munculnya ketegangan dan kebingungan bahkan bisa menjadi rentan mengalami anxiety pada orangtua dan bahkan berdampak pada permasalahan psikologis anak (Alwisol, 2011).

Berdasarkan latar belakang di atas, diperlukan suatu intervensi yaitu terapi realitas yang di fokus kan untuk meningkatkan penerimaan orangtua pada ABK. Sejauh ini, penelitian lain lebih berfokus pada individu yang menderita kekhususan baik dari segi psikologis maupun biologis, sedangkan dalam hal ini seseorang yang merawat juga akan mengalami tingkat stress tersediri. Selain itu, penelitian terdahulu lebih berfokus pada bagaimana dampak psikologis yang dialami orangtua yang memiliki anak berkebutuhan khusus tanpa adanya perlakuan untuk 
membantu orangtua yang memiliki anak berkebutuhan khusus dalam menerima situasi yang tidak sesuai dengan apa yang diharapkan.

Pada penelitian ini, peneliti memberikan intervensi atau perlakuan yang belum pernah diberikan kepada orangtua yang memiliki tingkat rendah dalam penerimaan pada anak yang memiliki keterbatasan. Hasil penelitian terdahulu, terapi realitas diberikan kepada individu yang memiliki gangguan pada bagaimana Hasil surve yang dilakukan oleh (Arzamarski, Caley, Watson \& Mary, 2011) menunjukkan bahwa terapi realitas memiliki dampak jangka panjang pada peserta sebelumnya karena mereka menggunakan konsep CT/RT untuk memperbaiki kehidupan mereka sendiri. Terakhir, dibandingkan dengan program pascasarjana lainnya, siswa menganggap kelas tersebut menjadi berharga. Secara keseluruhan, temuan ini menunjukkan bahwa siswa menganggap terapi Realitas memiliki manfaat yang baik untuk kehidupan mereka. Hasil penelitian menunjukkan bahwa terdapat pengaruh pemberian terapi realitas kepada psoriasis, yaitu pasien mengalami penurunan tingkan depresi setelah diberikan perlakuan berupa terapi realitas (Kusuma, 2016).

Sasaran utama pada intervensi ini pada penerimaan, sehingga pola asuh orangtua pada anak dapat berjalan dengan lancar dan tepat. Sesuai dengan pendapat (Meadan, Halle, \& Ebata, 2010) jika orangtua bisa menerima kondisi anak, sehingga anak bisa berkembang dengan baik. Keunikan dalam penelitian ini adalah terapi ini belum pernah diteliti secara bersamaan, yaitu diberikan kepada orangtua yang memiliki anak berkebutuhan khusus, sedangkan penelitian terdahulu lebih berfokus pada pasien dengan penyakit kronis. Terapi Realitas merupakan terapi yang berfokus pada perilaku saat ini. Terapis bertugas sebagai guru dan model untuk subjek dengan cara yang dapat membantu subjek menghadapi kenyataan dan terpenuhi kebutuhan-kebutuhan dasar tanpa merugikan dirinya sendiri maupun orang lain.

Glasser menyatakan bahwa hal-hal yang membawa perubahan perilaku saat penolakan hingga pada tahap mampu menerima kenyataan yang terjadi adalah (1) Subjek mampu mengungkapkan apa yang diinginkan, kebutuhan, dan apa yang diyakini tentang kondisi yang sedang dihadapi. (2) Subjek berfokus pada perilaku 
saat ini, artinya tidak terpaku pada masalah lampau. (3) Subjek bersedia untuk mengoreksi perilaku, situasi dimana subjek menilai sesuatu yang telah dilakukan terhadap dirinya sesuai dengan norma yang ada di masyarakat. (4) Subjek menentukan perubahan dan komitmen pada apa yang telah direncanakan.

Glasser (2003) tujuan terapi realitas adalah: 1) Membantu seseorang dapat merawat diri sendiri agar mampu menentukan dan menjalankan perilaku atau sikap dalam bentuk nyata. 2) Memotivasi individu untuk bisa berani bertanggung jawab sesuai dengan kemampuan dan keinginan pada masa perkembangan dan pertumbuhannya. 3) Mengembangkan rencana nyata dan realistis untuk mencapai tujuan yang telah ditetapkan. 4) Keberhasilan perilaku dapat dikaitkan dengan keberhasilan kepribadian yang telah dicapai, dengan menanamkan nilai pada individu untuk merubahnya sendiri. 5) Intervensi ini di titik beratkan pada kesadaran akan kedisiplinan dan tanggungajawab.

Seseorang yang mampu menerima diri berarti telah menyadari, memahami dan menerima diri apa adanya, disertai dengan apa yang diinginkan sehingga bisa hidup dengan baik dan tanggung jawab (Hati, 2007). Penerimaan diri berkaitan dengan kesehatan fisiologis dan psikologis seseorang (Hjelle \& Ziegler, 1981, Munandar 2001). Seseorang yang memiliki penerimaan diri yang baik bisa dilihat dari selera makan yang baik, tidur dengan baik, dan menikmati kehidupan seks. Dilihat dari sisi biologis dasar; kehamilan, menstruasi, dan proses menua merupakan bagian dari proses perkembangan yang bisa diterima dengan rasa bahagia. Hasil penelitian yang dilakukan oleh (Mickel, Mills \& Holmes, 2011) menunjukkan bahwa terapi realitas dapat dimanfaatkan sebagai referensi pengalaman dan kebutuhan unik dari Wanita berkulit Hitam yang signifikan untuk memahami hubungan antar sistem sosial, psikologis dan budaya yang dipengaruhi oleh perilaku manusia.

Menurut Glasser (2003) ada empat kebutuhan yang bersifat psikologis yaitu: (1) Kebutuhan memiliki teman, keluarga dan dicintai, (2) Kebutuhan untuk berkuasa (meliputi: harga diri, dikenal, diakui dan persaingan), (3) Kebutuhan bahagia (belajar), (4) Kebutuhan bebas untuk memilih. Keempat kebutuhan psikologis tersebut berusaha untuk dipenuhi secara seimbang dan saling berkaitan 
atau berpengaruh jika individu bisa memenuhi secara optimal dalam kehidupannya. Jika salah satu kebutuhan mendominasi dan yang lain ditolak, maka akan mengabaikan total behavior. Dampak yang terjadi akibat ketegangan dan ketidaksesuaian yang dirasakan menyebabkan permasalahan psikis yang menimbulkan konflik pada diri sendiri dan konflik terhadap oranglain.

Menyikapi hal tersebut diperlukan suatu intervensi untuk menghambat permasalahan psikologis yang muncul akibat ketidaksesuaian antara harapan yang diinginkan orangtua dengan realitas. Terapi realitas melihat subjek sebagai proses rasional yang berfokuskan pada perilaku sekarang. Bearti bahwa individu fokus untuk mengetahui perilaku yang bisa dilihat daripada tujuan bawah sadarnya, sehingga subjek bisa menilai apakah perilaku tersebut efektif pada saat memenuhi kebutuhan atau sebaliknya. Apabila yang dimunculkan dari perilaku tersebut tidak memuaskan subjek, maka terapis memberikan arahan untuk merancang perilaku dari peluang-peluang yang bertanggungjawab. Yang dimaksud perilaku bertanggungjawab yaitu perilaku yang sesuai dengan apa yang terjadi. Glasser menyebutkan sebagai menerima kenyataan. Hal tersebut bearti bahwa, terapi realitas mampu menolong subjek dalam mengatasi tekanan dari masalah yang dialami. Penelitian oleh (Mosallanejad \& Jahromi, 2014) terdapat perbedaan antara nilai rata-rata metakognisi dan harapan sebelum dan sesudah intervensi kelompok eksperimen. Namun, tingkat stres tidak berbeda secara statistik dalam dua kelompok. 


\section{Gambar 1. Skema terbentuknya masalah}

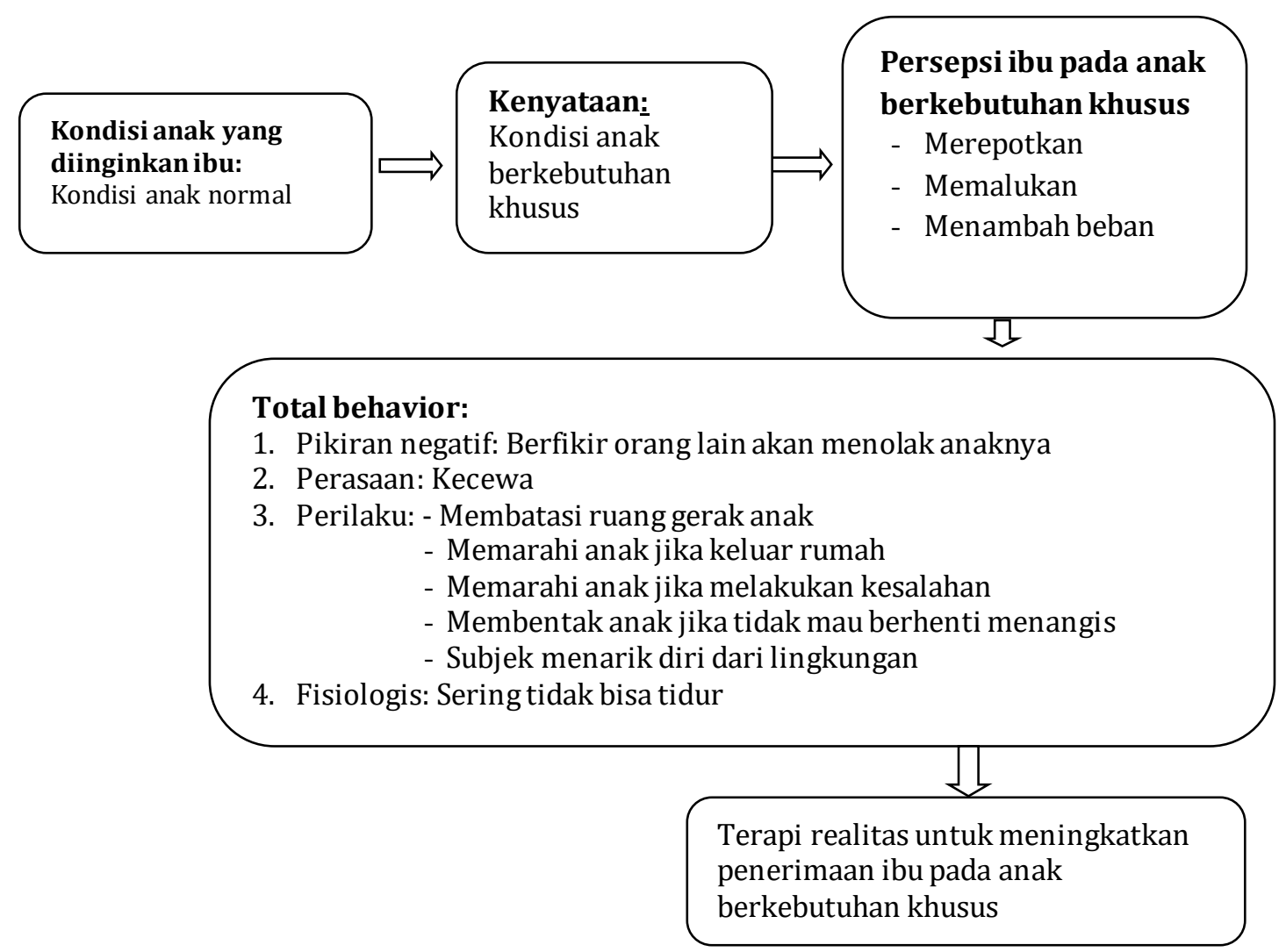

\section{METODE}

Penelitian ini menggunakan metode penelitian kuantitatif yang menggunakan pre eksperimental dengan desain eksperimen yang telah digambarkan sebagai berikut:

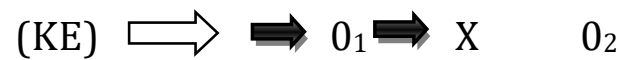

$$
\begin{array}{ll}
\text { Keterangan } & : \\
(\mathrm{KE}) & : \text { Kelompok Eksperimen } \\
\mathrm{X} & : \text { Perlakuan } \\
\mathrm{O}_{1} & : \text { Pre-test } \\
\mathrm{O}_{2} & : \text { Posttest }
\end{array}
$$

Subjek Penelitian

Subjek penelitian berjumlah 5 orang ibu rumah tangga rentang usia 35-41 Tahun yang memiliki anak berkebutuhan khusus dan memiliki nilai rendah dalam penerimaan pada anak. Berdasarkan desain penelitian, teknik penelitian menggunakan purposive sampling, yaitu berdasarkan pertimbangan peneliti yang 
bertujuan untuk mendapatkan informasi yang relevan dengan tujuan peneliti (Darmadi, 2013).

Rancangan dan prosedur intervensi: 1) Tahap Persiapan: Membuat instrumen penelitian; 2) Tahap Pelaksanaan: Pemilihan subjek dilakukan dengan melakukan screening dengan melakukan wawancara kepada guru sekolah dan kepada subjek untuk melihat terlebih dahulu orangtua yang memiliki kriteria penolakan yang tinggi. Setelah itu orangtua yang memiliki kriteria penolakan yang tinggi mengisi skala; Sampel penelitian diambil Setelah melakukan screening, maka peneliti meminta izin subjek untuk mengikuti penelitian ini dengan mengisi informed consent yang telah disetujui oleh subjek, kemudian sama-sama menetapkan jadwal untuk pelaksanaan intervensi terapi realitas; Setiap sesi berlangsung kurang lebih 40-60 menit dilakukan secara bertahap. 3) Pelaksanaan Intervensi

Modul Terapi Realitas terdapat sembilan sesi, intervensi dilakukan di rumah subjek berdasarkan kontrak yang telah disepakati. Berikut sesi-sesi dalam pelaksanaan terapi:

Terapi dirancang sebanyak 9 sesi dilakukan selama 40-60 menit dan dilakukan secara bertahap, sesi 1 yaitu membangun report dengan memberitahukan kepada subjek mengenai tujuan diadakannya intervensi dan membuat kesepakatan agar tetap mengikuti sesi-sesi intervensi. Membuat nyaman selama proses intervensi dan dilanjutkan pengisian skala pretest untuk mengetahui data sebelum diberikan terapi, terkait tingkat penerimaan orangtua. Sesi 2 menjelaskan materi tentang anakku istimewa: pahami kondisi anak, bakat dan orangtua diharapkan mampu menerima kondisi anak dengan tanpa syarat, yang bertujuan untuk memberikan kesempatan kepada subjek untuk memahami keistimewaan anak (definisi ABK, penyebab, karakteristik, pola perkembangan) dan bakat alami yang dimiliki anak. Sesi 3 identifikasi kejadian, pikiran, perasaan, perilaku supaya subjek bisa menerima perasaan dan pikiran negatif yang tidak terkontrol dalam menyikapi keistimewaan anak. Sesi 4 orangtua memberikan dukungan kepada anak seperti menghargai dan menghormati anak sebagai pribadi yang unik, sehingga mampu mengembangkan segala potensi dan menjadi individu yang mandiri. Sesi 5 memberikan pengetahuan tentang ikatan batin antara 
orangtua dan anak bisa memunculkan rasa aman secara emosional, nyaman, dan bahagia sesuai dengan dirinya. Sesi 6 review materi sebelumnya. Sesi 7 Memberikan kesempatan untuk belajar menerima keistimewaan anak dan mencintai tanpa syarat melalui pendekatan spiritual (sabar dan syukur). Sesi 8 Identifikasi rencana yang akan dilakukan untuk menjaga dan meningkatkan kemampuan dalam bersikap dengan tepat. Terminasi. Sesi 9 follow up Instrumen

Instrumen dalam penelitian ini menggunakan skala ukur yang dibuat sendiri oleh peneliti berdasarkan aspek dari penerimaan diri dengan nilai reliabilitas sebesar $\alpha=0,880$. Skala ini terdapat 12 pernyataan dan diukur melalui 4 kriteria yaitu: SS 4, S 3, N 2, TS 1, STS 0. Contoh item: a) Saya menyembunyikan anak saya, b) Saya memuji anak saya

Pengambilan Data

Metode pengumpulan data menggunakan: (a) Pengamatan (b) Wawancara, (c) Dokumentasi. Pada penelitian ini, dokumen yang dikumpulkan berupa catatancatatan atau fail yang memiliki keterkaitan dengan fokus penelitian ini, dan (d) skala pengukuran.

Jenis data yang digunakan adalah data interval dengan menggunakan Analisis data berupa Uji-t dengan sampel berpasangan, yang digunakan untuk menguji signifikansi perbedaan dua mean dari dua distribusi.

Intervensi yang diberikan kepada subjek adalah terapi realitas. Terapi ini menitik beratkan pada perilaku sekarang dan saat ini. Yakni, subjek diminta untuk melihat perilaku yang muncul daripada perilaku-perilaku bawah sadarnya. Sehingga, subjek bisa menyadari apakah sikap subjek itu sendiri sudah efektif dalam memenuhi kebutuhannya atau tidak. Jika subjek merasa perilaku yang dimunculkan membuat subjek merasa tidak puas, maka peneliti mengarahkan subjek untuk mencari peluang-peluang yang bisa dilaksanakan melalui membentuk rencana dan perilaku yang lebih bertanggungjawab.

Maksudnya adalah perilaku yang sesuai dengan kondisi yang ada, Glasser menyebut sebagai menerima kenyataan. Sehingga, subjek mampu mengatasi tekanan yang muncul karena adanya permasalahan yang dialami. Glasser, 
mengatakan bahwa suatu kondisi yang mengarahkan terjadinya perubahan perilaku dari penolakan ke tahap menerima pada saat proses intervensi yaitu:

Subjek bisa mengungkapkan apa yang diinginkan, apa yang dibutuhkan dana pa yang didapat mengeksplorasi harapan, apa yang dibutuhkan, dan apa yang dipersepsikan terkait situasi yang dihadapi. Di sini subjek termotivasi untuk memahami dan mengartikan apa yang diinginkan untuk memenuhi kebutuhan. Setelah mengetahui apa yang di inginkan, subjek lalu mengevaluasi apakah yang ia lakukan selama ini memenuhi kebutuhan-kebutuhan tersebut.

Subjek fokus pada perilaku sekarang tanpa terpaku pada permasalahan masa lalu. Tahap ini merupakan kesadaran subjek untuk memahami bahwa kondisi yang dialaminya bukanlah hal yang bisa dipungkiri. Kemudian mereka mulai menentukan alternatif apa saja yang harus dilakukan. Di sini subjek mengubah perilaku totalnya, tidak hanya sikap dan perasaan, namun yang diutamakan adalah tindakan dan pikiran.

Subjek menghendaki mengevaluasi perilakunya, merupakan kondisi dimana subjek membuat penilaian tentang apa yang telah ia lakukan terhadap dirinya sendiri berdasarkan sistem nilai yang berlaku di masyarakat apakah yang dilakukan dapat menolong dirinya atau sebaliknya, apakah hal itu bermanfaat sudahkan sesuai dengan aturan dan apakah realistis atau dapat dicapai. Mereka menilai kualitas perilakunya. Sebab, tanpa ada penilaian pada diri sendiri perubahan akan sulit terjadi. Evaluasi ini mencangkup seluruh komponen perilaku total.

Subjek mulai menetapkan perubahan yang dikehendakinya dan komitmen terhadap apa yang telah direncanakan. Rencana-rencana yang ditetapkan harus sesuai dengan kemampuan subjek, bersifat konkrit atau jelas pada bagaimana dari perilakunya yang akan diubah, realitis dan melibatkan perbuatan positif.

Pada terapi realitas ini terdapat 9 sesi, pada masing-masing sesi dilaksanakan selama 40-60 menit dan dilakukan secara bertahap, sesi 1 dilakukan dengan memberitahukan kepada subjek mengenai tujuan diadakannya intervensi, dan membuat kesepakatan dengan peserta agar tetap mengikuti selama kegiatan intervensi. Membuat nyaman selama proses intervensi dan dilanjutkan pretest 
berupa pengisian skala penerimaan pada anak berkebutuhan khusus untuk mendapatkan data awal. Sesi 2 menjelaskan materi tentang anakku istimewa: pahami kondisi anak, bakat dan menerima keberadaan dengan tanpa syarat, dengan tujuan untuk memberikan kesempatan kepada subjek untuk memahami kekhususan yang dimiliki anak serta mengetahui kelebihan yang dimiliki anak. Sesi 3 identifikasi (kejadian, pikiran, perasaan, perilaku) agar mampu untuk mengontrol perasaan dan pikiran yang tidak menyenangkan terkait kondisi anak. Sesi 4 pemberian dukungan berupa menghargai dan menghormati anak, membantu mengembangkan potensi yang dimiliki anak, sehingga anak menjadi pribadi yang mandiri. Sesi 5 pengetahuan tentang ikatan batin antara orangtua dan anak secara emosional mampu untuk menciptakan rasa aman dan tentram. Sesi 6 review materi sebelumnya. Sesi 7 Memberikan kesempatan untuk mencoba tanpa syarat menerima, mencintai keunikan anak melalui pendekatan spiritual. Sesi 8 mengklasifikasikan rencana-rencana yang dapat dilakukan dalam mempertahankan kemampuan bersikap baik.

\section{HASIL DAN PEMBAHASAN}

Tabel 1. Hasil uji normalitas

\begin{tabular}{|ll|r|r|}
\hline & & Pre.test & \multicolumn{1}{|c|}{ Post.test } \\
\hline $\mathrm{N}$ & 5 & 5 \\
Normal & Mean & 39.8000 & 90.8000 \\
Parameters & Std. Deviation & 9.54987 & 3.34664 \\
a,b & & .255 & .276 \\
Most & Absolute & .255 & .276 \\
Extreme $\quad$ Positive & -.145 & -.140 \\
Differences & Negative & .569 & .618 \\
Kolmogorov-Smirnov Z & .902 & .840 \\
Asymp. Sig. (2-tailed) &
\end{tabular}

Sumber: Data Penelitian Diolah (2019)

Hasil uji normalitas terhadap data pre test dan post test diperoleh nilai signifikansi lebih dari 0,05 ( $p>0,05)$ sehingga data yang digunakan berdistribusi normal. 
Proses intervensi yang berlangsung 9 sesi menunjukkan adanya perubahan sebelum dan sesudah diberikannya intervensi atau perlakuan. Yaitu, Subjek mengalami peningkatan pada aspek penerimaan pada anak berkebutuhan khusus.

Hasil paired t-test diperoleh nilai t sebesar 11,731 dengan nilai signifikansi sebesar 0,000 $(\mathrm{p}<0,05)$ sehingga data yang terdapat pengaruh pemberian perlakuan terhadap data test. Hal tersebut menunjukkan bahwa orangtua dengan tingkat penerimaan anak dengan kebutuhan khusus dapat meningkat melalui pemberian terapi realitas.

Tabel 2. Hasil paired t-test

\begin{tabular}{|cc|c|c|c|c|}
\hline & & Mean & $\begin{array}{c}\text { Std. } \\
\text { Deviation }\end{array}$ & t-statistics & P-value \\
\hline \multirow{2}{*}{ Pair 1 } & Pre.test & 39.8000 & 9.54987 & 11.731 & 0.000 \\
& Post.test & 90.8000 & 3.34664 & & \\
\hline
\end{tabular}

Sumber: Data Penelitian Diolah (2019)

Pada Tabel 2 menunjukkan nilai rata-rata pre tes dan post tes terhadap tingkat penerimaan pada anak. Skor tingkat penolakan sebelum diberikan perlakuan berupa terapi realitas sebesar 39.80 dan skor tingkat penolakan setelah terapi yaitu 90.80. Hasil skor tersebut berarti bahwa ada penurunan pada tingkat penolakan ibu terhadap anak, kondisi tersebut berbeda ketika orangtua belum mendapatkan terapi, yaitu ibu cenderung menunjukkan perilaku yang negatif pada anak seperti (mengucilkan, memarahi, malu). Sehingga intervensi ini memberikan peningkatan penerimaan ibu pada anak yang memiliki keterbatasan.

Hasil intervensi pada tahap satu adalah subjek bersedia mengikuti intervensi dan mampu untuk memahami prosedur dalam intervensi. Tahap dua proses konseling, hasil pada tahap ini menunjukkan bahwa subjek bisa memahami dan menerima keistimewaan anak, subjek juga bersedia untuk mencari kelebihan dan bakat anak, serta berusaha untuk menerima keistimewaan anak. Namun, pada tahap ini dua dari ke tiga subjek belum yakin untuk bisa menerima kondisi anak, namun setelah dijelaskan kembali materi tentang anakku istimewa, subjek bersedia untuk melaksanakan tugas tugas dari terapis untuk belajar memahami dan menerima kondisi anak dengan tanpa syarat. 
Hasil dari sesi tiga didapatkan kebutuhan yang belum terpenuhi oleh subjek yaitu, pikiran negatif tentang oranglain yang menolak anak nya, dari pikiran terebut muncul perasaan kecawa yang kemudian berdampak pada munculnya perilaku negatif kepada anak yaitu, membatasi ruang gerak anak, memarahi anak jika keluar rumah, memarahi anak jika melakukan kesalahan, membentak anak jika tidak mau berhenti menangis, Subjek menarik diri dari lingkungan. Dampak lain yang diakibatkan dari tidak terpenuhinya kebutuhan tersebut, subjek mengalami psikosomatis seperti susah tidur, yang kemudian membuat tubuh subjek menjadi lemas dan sesekali keluar dingin dan sakit.

Sesi empat, lanjutan dari sesi sebelum nya, pada sesi ini subjek terlihat mulai bisa menyadari bahwa apa yang subjek pikirkan dan rasakan adalah kurang tepat dan masing-masing subjek mampu memberikan dukungan untuk bisa saling mengontrol emosi dan berpikir positif. Subjek sepakat melaksanakan tugas untuk bisa menghormati anak, membantu mencari dan mengembangkan potensi anak. Kemudian hasil dari sesi lima yaitu, setelah melaksanakan sesi sebelum nya, subjek memahami seberapa besar kontribusi ikatan batin ibu dan anak untuk membantu perkembangan emosional anak supaya bisa optimal, subjek bisa menciptakan rasa aman dan tentram pada anak.

Sesi enam review, pada sesi ini, 1 dari 5 subjek mengatakan kesulitan untuk bisa mengontrol emosi, ketika anak melakukan kesalahan subjek langsung marah dan berkata kasar kepada anak. Namun, setelah emosi negatif subjek muncul, subjek merasa menyesal dan perilaku tersebut terus berulang ketika anak melakukan kesalahan. Pada saat evaluasi, subjek tersebut masih merasakan emosi negatif yaitu marah dan terus menangis karena merasa bahwa belum bias menerima realita saat dan menyalahkan dirinya sendiri, kemudian terapis memberikan relaksasi untuk menstabilkan emosi subjek dan kemudian mengulangi materi anakku istimewa, hasil pada tahap ini didapatkan bahwa masing-masing dari subjek berkomitmen berusaha untuk memperlakukan anak dengan lebih baik dari sebelumnya, dan masing-masing dari subjek saling memberikan dukungan dan motivasi sehingga pada tahap ini masing-masing dari subjek mengatakan bahwa perasaannya saat ini jauh lebih baik dari sebelumnya. 
Setelah subjek merasa sudah tenang dan siap melanjutkan sesi berikutnya, terapis memulai sesi ke tujuh. Hasil dari sesi ke tujuh yaitu, masing-masing dari subjek lebih mendekatkan diri kepada Tuhan, mendengarkan ceramah dari media sosial tentang ujian dan hikmah yang diberikan Tuhan kepada umat nya, subjek juga bersedia dengan ikhlas belajar secara konsisten menerima keistimewaan yang dimiliki anak.

Hasil sesi delapan adalah masing-masing subjek membuat strategi untuk bisa dengan konsisten bersikap baik, subjek 1 membuat strategi untuk mengambil air wudhu dan istighfar pada saat anak melakukan kesalahan. Subjek 2, pada saat emosi itu muncul, subjek segera merangkul anak dengan mengatakan anakku sayang, anakku hebat, anakku pintar. Subjek 3, memilih untuk shalat sunah ketika emosi itu akan muncul. Subjek 4, lebih memilih untuk menyerahkan anak kepada suami ketika emosi itu akan muncul dan mendekati anak ketika emosi tersebut sudah mulai terkontrol. Jika pada saat emosi itu muncul dan suami tidak ada di rumah, subjek memilih untuk mendengarkan lagu jawa dan pada saat meninggalkan anak subjek dengan segera mengalihkan pikiran negatif tersebut dengan mengubah ke pemikiran yang positif sehingga tidak terlalu lama emosi yang ia dirasakan. Subjek 5, memilih untuk diam sejenak dan mengatur pernapasan atau relaksasi ketika anak melakukan kesalahan, dan kemudian memberikan pengertian kepada anak. Walaupun, menurut subjek penjelasan yang diberikan kepada anak tidak bisa dipahami oleh anak, namun subjek yakin akan naluri anak jika suatu saat anak akan bisa memahami maksudnya.

Sesi berikutnya yaitu terminasi, subjek bersedia dan memahami jika sesi intervensi sudah selesai, pada tahap ini masing-masing mengucapkan terima kasih terapis dan meminta kepada terapis untuk memberikan konseling di lain hari sehingga harapan subjek bisa terus dengan sabar merawat anak dengan berkebutuhan khusus. Tahap akhir yaitu evaluasi dan follow up dapat dilihat perubahan subjek melalui wawasan (insight) bagaimana subjek mampu untuk menyikapi kondisi anak sehingga tidak terjadi permasalahan pada ibu maupun anak yang diakibatkan oleh penolakan ibu. Pada awalnya subjek menyikapi dengan 
negatif kehadiran anak, namun setelah pemberian intervensi tingkat penolakan subjek terhadap kondisi anak.

Intervensi berupa terapi realitas yang diberikan kepada subjek telah mencapai tujuan yang diharapkan yaitu, setelah pemberian terapi realitas menunjukkan bahwa terdapat peningkatan pada skor post test pada skala penerimaan ibu yang memiliki anak berkebutuhan khusus. Hal tersebut menunjukkan bahwa terapi realita secara efektif dapat meningkatkan penerimaan ibu yang memiliki anak berkebutuhan khusus. Sejalan dengan hasil penelitian yang dilakukan oleh (Mosallanejad \& Jahromi, 2014) menunjukkan ada perbedaan yang positif, dari pemberian terapi realitas dapat mengurangi tingkat stres pada kelompok eksperimen.

Hal tersebut bisa dilihat pada tabel 2 yaitu dari hasil paired $t$-test diperoleh bahwa nilai t sebesar 11,731 dengan nilai signifikansi sebesar 0,000 ( $p<0,05)$ sehingga data yang terdapat pengaruh pemberian perlakuan terhadap data tes. Hal tersebut menunjukkan bahwa orangtua dengan tingkat penerimaan anak dengan kebutuhan khusus dapat meningkat melalui pemberian terapi realitas. Artinya bahwa ada penurunan pada tingkat penolakan ibu terhadap anak, kondisi tersebut berbeda ketika orangtua belum mendapatkan terapi. Hasil penelitian ini sesuai dengan hasil penelitian yang dilakukan oleh (Maharatih, 2008), yaitu terdapat perbedaan perbaikan intensitas nyeri pada kelompok yang diberikan perlakuan dibandingkan dengan kelompok yang tidak mendapatkan perlakuan Ditemukan juga bahwa ada perbedaan perubahan pada skor CGI kualitas hidup yang lebih baik pada kelompok perlakuan dibandingkan dengan pada kelompok kontrol. Dapat disimpulkan bahwa terapi realitas efektif digunakan sebagai terapi tambahan (ajuvan) pada pasien dengan nyeri kronik dibandingkan.

Sebuah survei nasional yang dilakukan oleh Administrasi Sumber Daya dan Layanan Kesehatan (HRSA) menemukan bahwa 22\% dari semua rumah tangga dengan anak-anak memiliki setidaknya satu anak dengan kebutuhan khusus (US DHHS 2008). Hasil penelitian menunjukkan bahwa orangtua yang memiliki anak berkebutuhan khusus dan penyandang cacat memiliki beban pengasuhan yang lebih berat daripada orang tua dari anak-anak biasa dan mengalami tekanan 
mental dan emosional yang lebih besar (DeaterDeckard 2004; US DHHS 2008). Stres pengasuh ditemukan sangat tinggi di antara orang tua anak-anak dengan masalah emosional dan perilaku (Baker et al. 2002; DeaterDeckard 2004). Selain membahayakan kesejahteraan orang tua, stres dapat mengganggu hubungan orangtua-anak dan merusak perkembangan emosi, kognitif, dan fisik anak yang sehat (Perry-Jenkins \& Gillman 2000). Mengasuh anak dengan kebutuhan khusus juga dapat merusak keamanan ekonomi keluarga dengan mempersulit orangtua untuk menyeimbangkan pekerjaan dan pengasuhan.

Suatu kondisi yang tidak sesuai dengan konsep diri menjadi salah satu faktor memunculkan ancaman dan termanifestasi dalam bentuk kecemasan. Pada saat proses penyesuaian kondisi psikologis dan kesehatan mental pada individu, tergantung pada kongruensi atau kesesuaian antara konsep diri dan pengalaman. Hal tersebut yang menjadi permasalahan yang dialami subjek saat ini (Palmer, 2010). Subjek yang menginginkan anak normal akan tetapi real nya anak subjek memiliki keterbatasan yaitu mengalami down syndrom. Pada saat orangtua mengetahui kondisi anak setelah melalui proses terapi, maka subjek mampu untuk menerima anak dengan segala kelebihan dan kekurangan kondisi anak tanpa syarat.

Pada saat subjek berada di kesadaran penuh, subjek tidak lagi menolak atau mendistorsi persepsinya, sehingga dapat mengembangkan dan mengaktualisasikan dirinya secara bertahap, seperti menunjukkan sikap penerimaan terhadap anak seperti yang belum dilakukan selama ini. Penelitian lain tentang efektivitas terapi realita pada orang yang memiliki masalah kesehatan mental, menunjukkan bahwa terapi realitas efektif diberikan kepada individu yang mengalami masalah kesehatan mental, seperti kecemasan dan depresi. Efektivitas terapi ini tidak ada batasan pada individu dengan gejala ringan dan gejala sedang saja. Artinya, terapi ini efektif juga diberikan kepada individu yang mengalami masalah kesehatan mental baik berat dalam durasi yang lama (Gibbard \& Hanley, 2008). 


\section{SIMPULAN}

Hasil penelitian menunjukkan bahwa Terapi realita dapat meningkatkan penerimaan ibu pada anak berkebutuhan khusus. Penerimaan tersebut dapat membentuk perilaku subjek berupa, mampu untuk menghargai anak dan tidak membatasi ruang gerak anak. Anak juga mulai dekat dengan ibu, walaupun sesaat sempat kaget ketika ibu mendekati anak. Subjek lebih memperhatikan keterbatasan anak dengan melalui konsultasi ke ahli perihal kondisi anak serta mencari solusi dalam menyikapi keterbatasan tersebut.

\section{REFERENSI}

Alwisol. 2011. Psikologi kepribadian. Malang: UMM Press.

Arzamarski, Caley B., Watson \& Mary E. (2011). choice theory and reality therapy: perceptions of efficacy. International Journal of Choice Theory and Reality Therapy. $31: 1-96$

Baker, B. L., Blacher, J., Crnic, K. A., \& Edelbrock, C. (2002). Behavior problems and parenting stress in families of three-yearold children with and without developmental delays. American Journal of Mental Retardation, 107, 433444

Deater-Deckard, K. (2004). Parenting stress. New Haven, CT: Yale University Press. Deater

Deckard, K. (2005). Parenting stress and children's development: Introduction to the special issue. Infant and Child Development, 14, 111-115.

Faradina, N. (2016). Penerimaan diri pada orangtua yang memiliki anak berkebutuhan khusus. ejournal psikologi, 4,(4), 1-2

Glasser, W. (2000). Counseling with choice theory: The new reality therapy. New York: HarperCollins

Glasser, W. (2005). Treating mental health as a public health problem. Chatsworth, CA: William Glasser Institute.

Hidayat, D. R. (2011). Teori dan aplikasi psikologi kepribadian dalam subjekng. Bogor: Ghalia Indonesia.

James, K., B .7 Gilliland, E,.B,. (1998). Theories and strategies in counseling and psychotherapy:Fourth edition.

Kusuma, M., (2016). Terapi realitas untuk menurunkan derajat depresi pasien psoriasis. Tesis. Ppds Psikiatri Fakultas Kedokteran Uns Rumah Sakit Dr.Moewardi Surakarta 
Maharatih, G, (2008). Keefektifan terapi realitas pasien rawat jalan dengan nyeri kronik musculoskeletal pada unit rehabilitasi medik rumah sakit dr. Moewardi surakarta. Tesis. Universitas Sebelas Maret Surakarta

Meadan, H., Halle, J. \& Ebata, A. (2010). Families with children who have autisme spectrum disorders: Stress and Support. Exceptional Children. 77, (1), 7-36

Mickel, E, Mills, C \& Holmes, K, (2011). Defining the experiences of black women: a choice theory®/reality therapy approach to understanding the strong black woman. International Journal of Choice Theory and Reality Therapy, 31: 1-72

Mottern, A., \& Mottern, R. (2006). Choose wealth: A choice-theory-based financial management program. International Journal of Reality Therapy, 25,(2), 1622.

Mosallanejad, L, \& Jahromi, K., (2014). The impact of reality therapy on metacognition, stress and hope in addicts. Global journal of health science, $1,(6)$

Munandar, U. 2001. Bunga rampai psikologi perkembangan dari bayi sampai dengan lanjut usia. Dalam utami munandar (Ed.). Tanpa Tahun. Jakarta: Universitas Indonesia Press

Palmer, S. (2011). Subjekng dan psikoterapi. Yogyakarta: Pustaka Pelajar.

Perry-Jenkins, M., \& Gillman, S. (2000). Parental job experiences and children's well-being: The case of two-parent and single-mother working class families. Journal of Family and Economic Issues, 21, 123-147.

Rank, 0., (1987). 'The Beyond'". Journal of Humanistic Psychology, 35,(4), 54-110

Rogers, C.R. 1971. On becoming a person a therapist's view of psychotherapy. London: Constable \& Company. Ltd.

Weisler, S. (2006). Cancer as a turning point in life. International Journal of Reality Therapy, 26,(1), 27-28.

Wubbolding, R. E., Al-Rashidi, B., Brickell, J., Kakitani, M., Kim, R. I., Lennon, B., et al. (1998). Multicultural awareness: Implications for reality therapy and choice theory. International Journal of Reality Therapy, 17,(2), 4-6.

Yang, H.,L. Nhan, V.,N. Shin, Y.,J \& Ngo.h. (2012). Stigma and restriction on the social life of families of children with intellectual disabilities in Vietnam. Singapore medical journal, 53(7), 451-457 